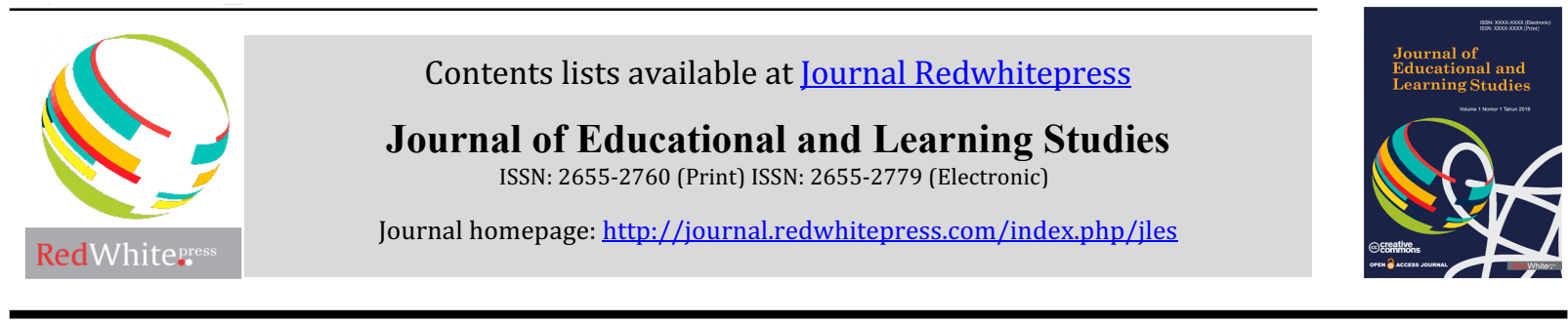

\title{
Relationship between Self-Control and Attitudes Towards Premarital Sexual Inisiation of Adolescence
}

\author{
Nada Annisah ${ }^{1}$, Mudjiran $^{2}$, Z. Mawardi Effendi ${ }^{3}$ \\ ${ }^{123}$ Guidance and Counseling Universitas Negeri Padang
}

\begin{tabular}{|c|c|}
\hline Article Info & ABSTRACT \\
\hline Article history: & \multirow{8}{*}{$\begin{array}{l}\text { Adolescents are at risk and need serious attention, especially in sexuality in the } \\
\text { development of adolescent life. Premarital sexual in Indonesia from time to } \\
\text { time is very worrying. Nowadays teens consider premarital sexual as a normal } \\
\text { and normal thing to do. Adolescent attitudes affect the behavior carried } \\
\text { out.This study reveals the relationship of self-control with attitudes toward } \\
\text { premarital sexual initiation of adolescence. This study uses the correlational } \\
\text { method and data collected from a sample of } 277 \text { students, which were found } \\
\text { using proportional random sampling techniques. Data were collected using a } \\
\text { self-control scale ( } 23 \text { valid items, }=0.876) \text {, and a scale of adolescent attitudes } \\
\text { about pre-wedding sexual behavior ( } 25 \text { valid items }=0.913 \text { ). Data were } \\
\text { analyzed using descriptive statistical methods, because to describe the object } \\
\text { studied through the sample as it is. The results show that there is a negative } \\
\text { and significant relationship between self-control and attitudes towards } \\
\text { premarital sexual initiation of adolescence. It can be concluded that the higher } \\
\text { the self control of students eating the lower the attitude of students towards } \\
\text { premarital sexual initiation of adolescence. }\end{array}$} \\
\hline Received Jan $12^{\text {th }}, 2020$ & \\
\hline Revised Mar 24 ${ }^{\text {th }}, 2020$ & \\
\hline Accepted May $26^{\text {th }}, 2020$ & \\
\hline Keyword: & \\
\hline Self Control & \\
\hline Attitudes toward Premarital & \\
\hline Sexual Inisiation & \\
\hline
\end{tabular}

C 2020 The Authors. Published by Redwhitepress.

This is an open access article under the CC BY-NC-SA license (https://creativecommons.org/licenses/by-nc-sa/4.0/

\section{Corresponding Author:}

Nada Annisah,

Universitas Negeri Padang

Email: nadaannisah31@gmail.com

\section{Introduction}

Adolescence is defined as a period of developmental transition between childhood and adulthood which includes biological, cognitive, and social-emotional changes. Teenagers are stages in human development that occur after an individual experiences a stage called puberty. Puberty is a stage where the individual has experienced glandular changes and can physically have sex and reproduce. And adolescents also experience sexual maturity (Santrock, 2007).

Adolescence lasting 12-21 years. Teenager the nation's next generation must have mental and behavioral ones challenge to be the generation that will become. But in reality many teenagers who have health problems reproduction, such as abortion, HIV / AIDS, STDs, and getting pregnant out-of-wedlock results from an understanding of sexual wrong and freedom of sexual behavior by teenagers (Gunarsa, 2011)

Sexual maturity in adolescents leads to sexual interest and teenage curiosity about sex. As a result, adolescents face great social and psychological consequences. This happens because of a great curiosity and try in adolescents because of biological and physical changes during puberty (Santrock, 2002).

The existence of sexual urges makes adolescents begin to be attracted to the opposite sex to establish love or what is commonly referred to as dating. The emergence of sexual drive and love for adolescents who are dating will make them want to always be close and make physical contact and physical closeness is what 
will lead to sexual behavior. The phenomenon of dating is now prevalent among adolescents, both early adolescence and adolescence (Amalia, 2015).

Teenagers who know information about sex, will arise expressions or responses to sex that will emerge from how teens behave. Premarital sexual attitudes of adolescents are influenced by many things, apart from knowledge factors are also influenced by cultural factors, others that are considered important, mass media, personal experiences, educational institutions, religious institutions, and emotions from within individuals. Premarital sexual attitudes in adolescents can be positive or negative, a positive attitude is the tendency of approaching or liking pre-marital sexual adolescents while the negative attitude of the action tendency is to avoid or hate premarital sexual behavior (Azwar, 2015).

Basically, premarital sexual behavior is sexual activity carried out by individuals with other people before marriage (Djamba, 2013). Some studies show the acute problem of sexuality in adolescents that continues to increase from year to year. This shows that the positive (permissive) attitude towards premarital sexual behavior has become increasingly widespread. The attitude of adolescents towards sex is seen from how the adolescent's behavior in responding to premarital sex. As for the behaviors that show positive and negative attitudes towards sexuality are such as placing sex under the function and purpose, the assumption that sex is disgusted, taboo and obscene, are not used as jokes and cheap chatter material, follow norms or rules in using it, discuss sex in context scientific or learning to understand themselves and others, and the use of good and right under the functions and absolute goals (Kusmiran, 2012).

The study of Rahman, Ismail, Ibrahim, Ali, Salleh, and Muda (2012) states that a positive attitude towards premarital sexual behavior of adolescents will encourage it to perform such behavior. Many factors cause premarital sexual behavior among adolescents, including the level of self-control teenagers have. Santrock (2007) says that delinquency committed by adolescents is a result of the failure of adolescents to develop sufficient self-control in terms of behavior.

The role of adolescent self-control is one of the most important elements of development tasks, namely strengthening self-control assuming the scale of values, principles or philosophy of life. Self-control describes individual decisions through cognitive considerations to bring together behaviors that have been arranged to improve certain outcomes and goals as desired. Self-control is one of the internal factors that cause adolescents to deviate from unhealthy sexual behavior such as permissiveness, lack of self-control, unable to take decisions about sexual life (Noor, 2005).

It can be concluded that an increase in premarital sexual behavior in adolescents in Indonesia from 2007 to 2012 with cases of 41,885 adolescents, $34.1 \%$ occurred among adolescents. And then it can also be seen that in adolescents in the city of Padang, they get adolescents who are netted in hotels, huts and dark places that commit acts that violate religious rules and norms so that there is an increase in premarital sexual behavior in adolescents in the city of Padang from 2016 to 2018. Premarital sexual behavior in adolescents is influenced by many factors namely, as much as $76.9 \%$ influenced by religiosity factors. $56.4 \%$ peer factors, $51.6 \%$ level of sexual knowledge, 50.2\% influence of pornographic media, and self-control, $63.1 \%$ (Amalia, 2015).

Phenomenon in the field shows that students are less able to control themselves, so they tend to engage in premarital sexual behavior, such as hugging / hugging, dating behind the school or behind the class closely and intimate there are also students who are caught watching porn videos. The explanation explained that adolescents who are unable to control themselves not to fall into premarital sex. Based on data released by the Indonesian Ministry of Health in 2014, it was found that 3.7\% of boys and 1.3 girls were known to have premarital sexual relations in 2007. This data was then renewed in 2012, where data obtained that $4,5 \%$ of teenage boys and $0.7 \%$ of teenage girls are known to have premarital sexual relations (Lisnawati \& Lestari, 2015).

Data from the West Sumatra Indonesian Child Protection Commission (KPAI) in 2016, there were 107 cases of sexual behavior, 17 cases were premarital sexual behavior in adolescents consisting of seven cases in junior high-school students and 10 cases in high-school students. 17 cases of sexual behavior $80 \%$ of them occurred in the city of Padang. Research conducted by the Indonesian Family Planning Association (PKBI) in Padang City found $10.5 \%$ of adolescents in active sexual behavior. Various cases in adolescents were found from the Padang City Civil Service Police Unit report. In 2016, 26 teenagers were found netted in hotels, huts, dark places such as the Padang beach grip stones and committed immoral acts or sexual behavior. In 2017, it increased to 48 teenagers who were netted in the raid. In 2018, there were already eleven teenagers with the same case (Nursal, Aprianti, Pratiwi, 2018).

Looking at cases of sexual behavior that occur among adolescents, especially in high-school students who can cause various kinds of negative effects. Therefore, it is necessary to conduct a study as a first step to determine the level of self-control of students with attitudes toward sexual behavior. 


\section{Method}

This research is a quantitative approach using a descriptive method. Descriptive research is research that describes systematically, actually, and accurately about the facts and the nature of a particular population, or tries to describe the phenomena that will be examined in detail (Joseph, 2013). Quantitative research methods provide quantitative or numerical descriptions and sampling from populations (Creswell, 2009). The targets in this study were high-school students namely SMA Negeri 15 Padang. Sampling in this study using a random sample. The sample of this study amounted to 277 people. The sampling technique uses proportional random sampling with data collection tools such as self-control scale. Self-control instrument has 30 items and is valid 23 items because rcount $>0.361$. For the reliability of the self-control variable of 0.876 .Data processing to determine the level of student self-control using SPSS version 20.

\section{Results and Discussions}

The results of testing the hypothesis of a self-control relationship with attitudes toward premarital sexual behavior in adolescents are as follows.

Tabel 23. Correlation Analysis Results Self-Control (X) with

Attitudes toward Premarital Sexual Behavior (Y)

\begin{tabular}{|c|c|r|}
\hline Variabel & \multicolumn{2}{|c|}{ Correlations } \\
\hline \multirow{2}{*}{ X with Y } & Pearson Correlation & $-0.271^{* *}$ \\
\cline { 2 - 3 } & & .000 \\
\cline { 2 - 3 } & & 277 \\
\hline
\end{tabular}

The results from the analysis were obtained from the amount of data as much as $n=277$ that the correlation coefficient of self-control with the variable attitude toward premarital sexual behavior that is equal to $r_{x y}=-0,271 * *$ with a significance of 0,000 . So it can be concluded that there is a negative and significant relationship between self-control and attitudes toward premarital sexual behavior of students, meaning that if self-control is high on the lower the students 'attitudes toward premarital sexual behavior and vice versa if students' self-control is low, then attitudes towards premarital sexual behavior of students will be high.

\section{SELF CONTROL}

Based on the results of data analysis it is known that self-control of student from Senior High School Number 15 Padang is in the high category. The results of data processing showed that students' self-control was in the high category at $76.17 \%$, in the medium category at $12.27 \%$, and in the very high category at $11.55 \%$. Furthermore, based on each sub variable, among others: 1) behavior control is in the high category. 2) cognitive control is in the high category. 3) decision control is in the high category.

The results of the analysis of the research data indicate that on average self-control is in the high category. This means that the self-control provided by students is good. Based on the achievement of each sub variable, it is known that all indicators are in the high category. This means that the average student has good self-control. The results of this study are in line with research conducted by Tripambudi \& Indrawati (2018) that someone who has high self-control tends to direct his behavior towards a positive, good way of thinking by focusing on things that bring benefits, and making decisions carefully.

\section{ATTITUDE TO SEXUAL TOWARDS PREMARITAL SEXUAL INISIATION OF ADOLESCENCE}

The results showed that on average adolescent attitudes towards free sex behavior were in the low or rejected category of 147 students or $53.07 \%$. This means that students at Senior High School Number 15 Padang has good attitudes, namely rejecting forms of premarital sexual behavior or not having a tendency to engage in premarital sex. Furthermore, in the medium category, there was 86 students or $31.05 \%$ of students who meant students considered sexual behavior to be normal, such as hugging, holding hands and making out with a partner while dating. Then in the very low category were 42 students or $15.16 \%$ students who strongly reject premarital sexual behavior. In the high category, there is two students or $0.72 \%$ of students who approve premarital sexual behavior. Furthermore, there are no students in the very high category.

The results of this study indicate that adolescent views on premarital sexual behavior such as holding 
hands, embracing / embracing, and other forms of premarital sexual behavior must be avoided. Darmasih research results (2009) concluded that there is an influence of knowledge, understanding of religious level, sources of information and the role of parents on free sex behavior in adolescents.

\section{RELATIONSHIP OF SELF CONTROL WITH ATTITUDE TO SEXUAL BEHAVIOR PREWEDDING}

Based on the results of the study showed that self-control has a negative and significant relationship to attitudes toward premarital sexual behavior. This finding was obtained based on data analysis that the relationship of self-control with attitudes toward premarital sexual behavior had Pearson Correlation -0.271 , with sig. (2-tailed) 0,000 . That is, self-control has a negative and significant relationship to adolescent attitudes towards premarital sexual behavior.

The results of the study it can be concluded that there is a negative and significant relationship between self-control and attitudes towards premarital sexual behavior. This is in accordance with research conducted by Arlyanti (2012) which states that there is a significant negative relationship between self-control and attitudes towards premarital sexual behavior. This means that the higher the self-control, the lower (negative) attitudes towards premarital sexual behavior. Conversely the lower the self-control, the higher (positive) attitudes toward premarital sexual behavior. Based on these data, that someone who has high self-control is someone who can manage situations, manage emotions, manage behavior and act rationally. Therefore, selfcontrol has an important role in adolescent attitudes towards premarital sexual behavior.

\section{Conclusions}

Self-control students of SMA Negeri 15 Kota Padang overall is in the high category. A student who has high self-control that is equal to $76.17 \%$ or many as 211 students. Attitudes toward premarital sexual behavior among students in Senior High School Number 15 Padang as a whole is in the low category. The students who have low premarital sexual behavior that is $53.07 \%$ or 147 students. There is a negative and significant relationship between self-control and adolescent attitudes towards premarital sexual behavior.

\section{References}

Amalia, E. J. (2015) Relationship between self-esteem and assertiveness with sexual behavior in adolescent senior high school State 9 Lempake Samarinda. Ejournal Psikologi, 3 (3).

Arlyanti, R. (2012). Hubungan antara kontrol diri dengan sikap terhadap perilaku seksual pada remaja Karang Taruna. Naskah Publikasi. Fakultas Psikologi, Universitas Muhammadiyah, Surakarta.

Azwar, S. (2015). Sikap manusia teori dan penerapannya. Yogyakarta: Pustaka Pelajar.

Creswell, J. W. (2009). Research design qualitative, quantitative and mixed methods approaches. Amerika: Sage Publications.

Darmasih, R. (2009). Faktor yang mempengaruhi perilaku seks pranikah pada remaja SMA di Surakarta. Doctoral dissertation. Universitas Muhammadiyah Surakarta.

Djamba, Y.K. 2013. Sexual Practices in Africa. A.K. Baumle (Ed.). International Handbook on The Demography of Sexuality Dordrecht. Springer.

Gunarsa, Y. S. D. 2011. Psikoligi Remaja. Jakarta : BPK Gunung Mulia.

Kusmiran, E. (2012). Kesehatan reproduksi remaja dan wanita. Jakarta: Salemba Medika.

Lisnawati \& Lestari, N.S. (2015). Faktor-faktor yang berhubungan dengan perilaku seksual remaja di cirebon. Jurnal Care, 3(1).

Noor, R. (2005). Hubungan antara kontrol diri dengan perilaku seksual remaja pada siswa SMK istiqomah Muhammadiyah 4 Samarinda. Jurnal Motiva, 268.

Nursal, D. G. A., Aprianti, \& Pratiwi, M. V. (2018). Perilaku seksual pada siswa SMA Negeri jalur mandiri Kota Padang. Jurnal Kesehatan Masyarakat, 2(2).

Rahman, A. A., Rahman, R.A., Ismail, S.B., Ibrahim, M. I., Ali, S.H., Salleh, H., \& Muda, W. A. M. W. (2012). Factors associated with attitude toward premarital sexual activities among school-going adolescents in Kelantan, Malaysia. AsiaPasific Journal of Public Healh, 20.

Santrock J. W. (2007). Remaja edisi 11.Terjemahan oleh Benedictine Widyasinta. Jakarta: Erlangga.

Santrock, J.W. (2002). Life-span development edisi 13 jilid 2, Terjemahan oleh Benedictine Widyasinta. Jakarta: Erlangga.

Tripambudi, B. \&Indrawati, E.,S. (2018) Hubungan Antara Kontrol Diri Dengan Perilaku Konsumtif Pembelian Gadget Pada Mahasiswa Teknik Industri Universitas Diponegoro. Jurnal Empati. 7(2)

Yusuf, A.M.( 2013).Metodologi penelitian kuantitatif,kualitatif \&penelitian gabungan. Jakarta: Kencana. 